\title{
Antioxidant Activity and Rancidity of Kefir Face Mask "Bedak Lotong" Incorporated with Various Levels of Temulawak (Curcuma xanthoriza Roxb)
}

\section{Dewi Ramadani, 2Ratmawati Malaka and 2Fatma Maruddin}

1Postgraduate of Animal Science Department, University of Hasanuddin, Indonesia

2Animal Science Department, University of Hasanuddin, Indonesia

Correspondence Author: Dewi Ramadani. Department of Animal Science and Technology, Faculty of Animal Science, University of Hasanuddin, Makassar 90245, Indonesia.

Tel: +628114457810 .

Received date: 12 February 2018, Accepted date: 12 April 2019, Online date: 20 April 2019

Copyright: (C) 2019 Dewi Ramadani, et al., This is an open-access article distributed under the terms of the Creative Commons Attribution License, which permits unrestricted use, distribution, and reproduction in any medium, provided the original author and source are credited.

\begin{abstract}
Formation of free radicals can be reduced with application of antioxidants, such as vitamin E, carotene, vitamin C, as well as usage of natural materials and chemicals capable of scavenging the radicals. Phenolic compounds are well known to exert antioxidative properties. "Bedak Lotong", a traditional product,was rich in phenols, derived from its natural ingredients such as black glutinous rice (Oryza Sativa L.glutinosa), temulawak (Curcuma xanthoriza Roxb), and tamarind (Tamarindus indicia L.). This present work aimed to evaluate antioxidant activity and TBA value of kefir mask "Bedak Lotong". One way-completely randomized design was arranged, with percentage of temulawak $(0 \%, 15 \%, 30 \%$, and $45 \%)$ as a single factor. The results demonstrated that higher proportion of temulawak added in kefir mask "Bedak Lotong" could produce a higher antioxidant activity, which in turn, leads to reduction of TBA value, indicating that fat oxidation or rancidity was reduced.
\end{abstract}

Keywords: Oxidation, Antioxidant, black glutinous rice (Oryza Sativa L.glutinosa), temulawak (Curcuma xanthoriza Roxb), tamarind (Tamarindus indiciaL.), kefir.

\section{INTRODUCTION}

Kefir was traditionally made from fresh milk and fermented by kefir grain [4, 20], containing a mixture of bacteria and yeasts. During fermentation, these microorganisms produce lactic acid and flavor compounds, while the yeast produced alcohol and $\mathrm{CO}_{2}$. Kefir was reported to possess a distinctive aroma and numerous active compounds, which may exert beneficial effects on human health. This fermented product can be a good source of nutrition for human health [24], while also offers advantages for face skin. Therefore, the use of kefir for a face mask is promising. The lactic acid in kefir may attenuate the growth of bacteria responsible for acne, including Propionibacterium acne and Sthapilocuccus epidermis [3, 14]. The lactic acid in kefir may also contribute to moisturizing and exfoliating. Besides, lactic acid inhibited tyrosinase activity causing skin tanning. Currently, the mask was prepared from diverse extracts, such as the root of "bengkoang" (Pachyrhizus erosus), lemon, cucumber, and turmeric. These ingredients are rich in bioactive compounds meaningful for skin care.

"Bedak lotong," referring to black powder in the local language, has been long known as traditional product originated from Bugis, South Sulawesi. It is traditionally used as skin treatment for Bugis women [1]. As a folk product, "bedak lotong” is also produced from natural materials such as black glutinous rice (Oryza Sativa L.glutinosa), temulawak (Curcuma xanthoriza Roxb), and tamarind (Tamarindus indicia). 
Black glutinous rice (Oryza Sativa L.glutinosa) can be a source of anthocyanin and natural colorants [23]. Anthocyanin serves as an antioxidant, in which it promotes skin brightening and inhibits the formation of smooth lines in face skin. Temulawak (Curcuma xanthoriza Roxb) contains a lot of curcumin, which exerts antioxidative and anti-inflammatory properties. Also, tamarind (Tamarindus indicia) contains flavonoid, saponin, and alkaloid, also responsible for antioxidant activity. Kefir mask can be possibly improved with the presence of "bedak lotong." This work aimed to investigate antioxidant activity and TBA value of kefir mask "bedak lotong."

\section{MATERIALS AND METHODS}

Main components for mask sample included dairy milk, kefir grain, black glutinous rice (Oryza Sativa L.glutinosa), temulawak (Curcuma xanthoriza Roxb), tamarind (Tamarindus indicia L.). Chemicals for analysis were DPPH reagent, TBA reagent, distilled water, alcohol $70 \%$, acetic acid 2\%, spiritus, tissue, buffer solution, $\mathrm{NaOH} 0,1 \%$, and phenolphthalein. Meanwhile, equipment for experiment included glass jar, pasteurization chamber, beaker glass, micropipette, tip, analytical balance, incubator, refrigerator, autoclave, Bunsen, $\mathrm{pH}$ meter, measuring flask, Erlenmeyer, titration unit, pipette, reaction tubes, freeze dryer, oven, ose, hotplate, spectrophotometer UV-VIS, vortex, and Kjeldahl.

The experiment was performed according to one way-completely randomized design. Dairy milk was sterilized. Sterilized milk was then incubated at $37^{\circ} \mathrm{C}$ for $24 \mathrm{~h}$ following the addition of $10 \%$ kefir grain. Then, the incubated mixture was filtered to separate kefir grain. "Bedak lotong” was made by mixing all ingredients: heated black glutinous rice (Oryza Sativa L.glutinosa), tamarind (Tamarindus indicia L.), and temulawak (Curcuma xanthorrhiza Roxb) at different concentrations $(0 \%, 15 \%, 30 \%$, and $45 \%)$. Kefir was then mixed with "bedak loton," then freeze-dried.

DPPH assay was performed to asses antioxidant activity. The sample was dissolved in methanol at a concentration of 10, 30, 50, 70 and $90 \mu \mathrm{g} / \mathrm{ml}$, then each added with $3,8 \mathrm{ml}$ of DPPH reagent 5,8 $\mu \mathrm{g}$ and $0,2 \mathrm{ml}$ of methanol, left for 30 min. Absorbance was measured spectrophotometrically at a wavelength of $515 \mathrm{~nm}$ [5]. For determination of TBA value, the sample was added with $\mathrm{HCl}$ and distilled water, then distilled at 300-600 watt for $10 \mathrm{~min}$. The distillate was transferred into a test tube and added with TBA reagent. The solution was made at covered test tube and heated in boiling water $75^{\circ} \mathrm{C}$ for 35 min. The test tube was then cooled by exposing it to flowing water, and analyzed for absorbance at a wavelength of $528 \mathrm{~nm}$, while a blank solution was used. TBA value was expressed as mg malonaldehyde/kg sample [2].

\section{RESULTS AND DISCUSSION}

The results showed that the proportion of temulawak (Curcuma xanthorrhiza Roxb) on the formulation of kefir mask "bedak lotong" contributed to its antioxidant activity, as depicted in Figure 1.

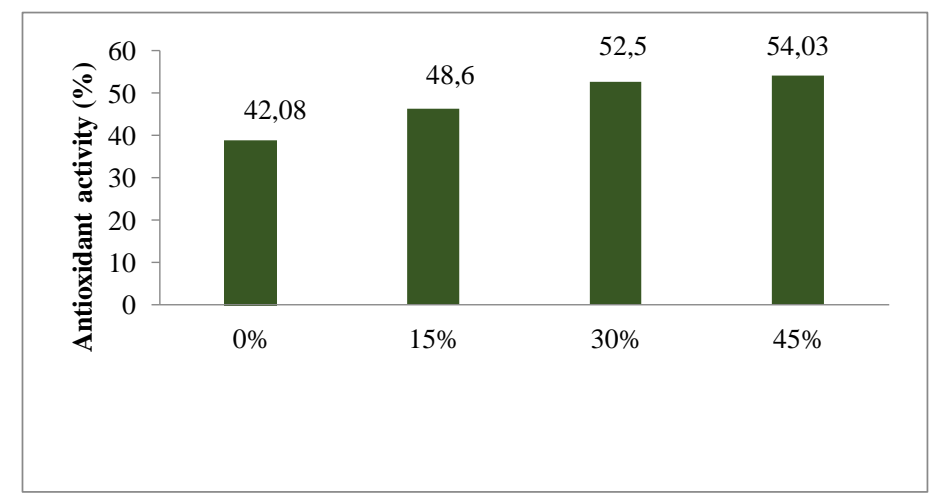

The proportion of temulawak (Curcuma xanthorrhiza Roxb) xanthoriza Roxb)

Figure 1. The difference in antioxidant activity of kefir mask "bedak lotong" enriched with temulawak (Curcuma

Presence of antioxidative compound enables to reduce the oxidative reaction, while also serve to eliminate the main cause of degenerative diseases and delay aging process [12]. The proportion of temulawak (Oryza Sativa L.glutinosa) and drying methods seemed to provide a remarkable increase in antioxidant activity of kefir mask "bedak lotong".

Statistically, the percentage of temulawak did not show a significant effect on antioxidant properties of the mask, although the antioxidant activity tended to be higher as more temulawak (Curcuma xanthoriza Roxb) was added. Curcuminoid in temulawak (Curcuma xanthoriza Roxb) refers to a mixture of active compounds called as curcumin. Curcuminoid has been recognized capable of neutralizing toxic and serving as an antioxidant agent against deleterious free radicals [7, 18]. The antioxidant properties of the rhizome seemed to be affected by harvesting age [13]. Also, a study found that the concentration of curcuminoid positively related to antioxidant activity [15]. 
Addition to curcumin, phenolic compounds and essential oils present in temulawak (Curcuma xanthoriza Roxb also contributed to antioxidant activity, since they are capable of scavenging free radicals and peroxide radicals, thereby effectively reducing lipid oxidation [9]. Phenolic compounds could bind oxygen, which makes it unavailable for oxidation [10, 17], and form complex with metals responsible for catalyzing oxidation process [8]. Also, the presence of anthocyanin in black glutinous rice [6] and saponin in tamarind [11] present in "bedak lotong” provides antioxidative activity.

Figure 2 demonstrated that a decrease in TBA value was observed in the presence of temulawak (Curcuma xanthoriza Roxb) in kefir mask "bedak lotong." Combination of "bedak lotong” and kefir was effective to lower TBA value.

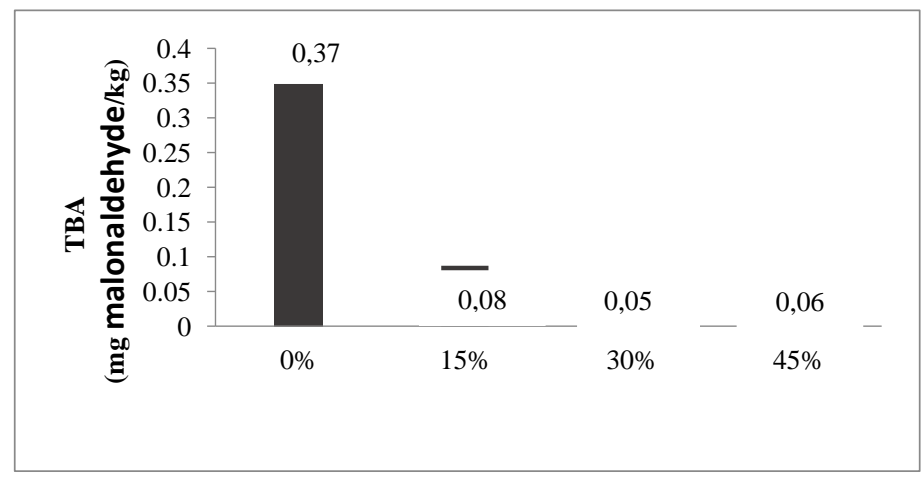

The proportion of temulawak (Curcuma xanthorrhiza Roxb)

Figure 2. The difference in TBA value of kefir mask "bedak lotong" enriched with temulawak (Curcuma xanthoriza Roxb)

Lipid oxidation was determined by using TBA (Thiobarbituric Acid) assay, which is based on the formation of malonaldehyde responsible for rancidity. Rancidity positively related to lipid oxidation, leading to a reduction of product quality.

Antioxidant activity of kefirplays essential role in stabilizing free radicals, preventing cells from damages. Kefir may donate more protons compared to unfermented milk; thus, kefir shows more powerful antioxidative activity to reduce lipid oxidation. The reduction of TBA value suggested that phenolic compounds and essential oil in temulawak (Curcuma xanthoriza Roxb) could better inhibit oxidative stress. Inhibition of oxidative stress closely relates to antioxidant properties of essential oil [16, 22]. Also, essential oils are responsible for the elimination of free radicals and peroxide radicals, leading to inhibition of lipid oxidation [8]. Enrichment of antioxidant-rich compounds to the product was effective to reduce the oxidation process [19]. Antioxidant enables to slow or prevent oxidation in which radicals more tended to react with antioxidant compared to other compounds. Higher antioxidant activity of kefir mask "bedak lotong” is associated with attenuation of TBA.

The results indicated that the proportion of temulawak (Curcuma xanthorrhiza Roxb) on kefir mask "bedak lotong” enhanced content of alcohol as presented in Figure 3.

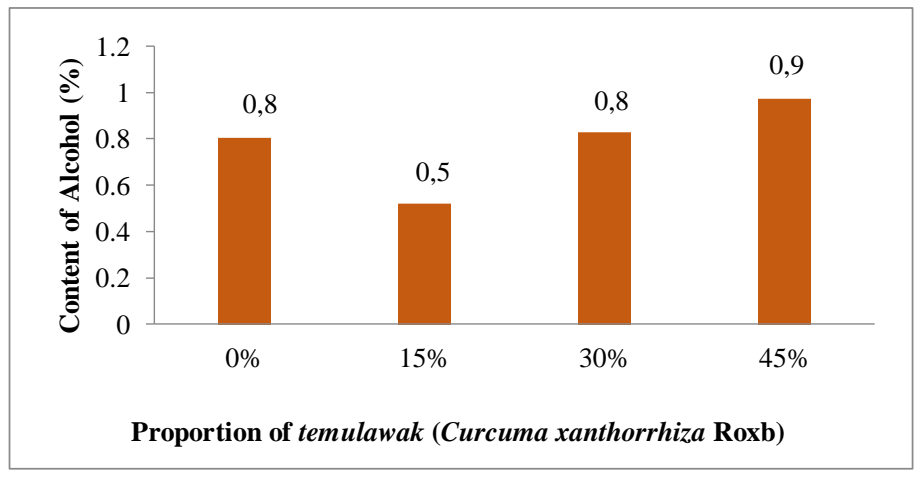

Figure 3. Content of alcohol in kefir mask "bedak lotong" as affected by different levels of temulawak (Curcuma xanthoriza Roxb)

Kefir constitutes an acidic-alcoholic fermented milk product with little acid taste, fermented by a microbial symbiotic mixture of bacteria and yeast [4]. Yeast generated $\mathrm{CO}_{2}$ and a limited amount of alcohol [21]. The alcoholic components may have a similar role to astringent, moisturizing and cleaning skin, as well as promoting deactivation of acne-causing bacteria, thereby reducing infection. The amount of temulawak (Curcuma xanthoriza Roxb added to kefir mask "bedak lotong" tended to alter the level of alcohol, as also affected by types of drying process. 
As aforementioned, Kefir is alcoholic product which contains approximately $1 \%$ lactic acid and $0,5-1 \%$ alcohol. The content of alcohol was affected by metabolic activity of yeast and heterofermentative bacteria generating alcohol. Temulawak contains 41,45\% starch and 9,48\% concentrated alcohol [13], in which these compounds were then converted by kefir micoorganisms into alcoholic component and lactic acid. The acidity of kefir may affect the capability of yeast to produce alcohol. Interestingly, lactic acid bacteria (LAB) and yeasts showed a mutual mechanism. Lactic acid produced by LAB, capable of inhibiting growth of LAB, was then used for bioactivity of the yeasts, while removal of $\mathrm{H}_{2} \mathrm{O}_{2}$ - generated by LAB - was carried out through enzymatic activity of catalase, an enzyme produced by yeasts. Subsequently, yeasts generated alcohol and particular compounds capable of promoting the growth of LAB [20].

\section{CONCLUSION}

Based on our experimental data, the antioxidant activity of kefir mask "bedak lotong" was higher due to enrichment with temulawak (Curcuma xanthoriza Roxb). The rise of antioxidant activity was responsible for the reduction of TBA value capable of preventing fat oxidation or rancidity.

\section{Acknowledgment}

Authors would like thank to Prof. Dr. Dwia Aries Tina Pulubuhu M.A. as a Rector of Hasanuddin University, and Post Graduate Program, Department of Animal Science and Technology. We also express sincere gratitude to technicians in the Laboratory of Biotechnology for Milk Processing and Laboratory of Integrated Biotechnology in Hasanuddin University for valuable supports on this work.

\section{REFERENCES}

[1] Annastasia, M. 2006. Menjelajah Tubuh Perempuan dan Mitos Kecantikan. LkiS, Yogyakarta.

[2] Apriyantono, A., D. Fardiaz, N.L Puspitasari, Sedarnawati, dan S. Budiyanto. 1989. Analisis Pangan. IPB Press, Bogor.

[3] Chen, C. 2006. Study on skincare properties of milk kefir whey. Journal Anim Sci. 6 (19), 905-908.

[4] Farnworth and Edward. 2005. Kefir- A complex Probiotic. Food Science and Technology Bulletin: Journal Funct. Food. 1,1 17.

[5] Gasic, U., S. Keckes, D. Dabic, J. Trifkovic, D.M. Opsenica, M. Natie and Z.Tesic. 2014. Phenolic profile and antioxidant activity of Serbian polyfroral honeys. Food Chem. 145, 599-607.

[6] Hamid A., Aiyela, Agbe, Usman, Ameen, and ALawal. 2010. Antioksidants: Its Medicinal and Pharmacological Aplications. African Journal of Pure and Applied Chemistry, 142-151.

[7] Kellof, G., J Crowell J, and L Kopelovic. 2000. Progress in cancer chemoprevention: Development of diet-derived chemopreventive agents. Symposium on diet, natural products and cancer Prevention: progress and promise. J Nutr.American Society for Nutritional Science. 130(2), 467-471.

[8] Khatun, M., Eguchi, S., Yamaguchi, T., Takamura, H. dan Matoba, T. (2006). Effect of thermal treatment on radicalscavenging activity of some spices. Food Science and Technology Research 12(3): 178-185.

[9] Kinsella, J.E., E Frankel, B German, and J Kanmer. 1993. Possible Mekanisme for the Protective role of Antioxidants in Wine and Plant Foods. J Food Technology. 4:5-89.

[10] Mandal 2009. "Antioxidants: A Review," Journal of Chemical and Pharmaceutical Research, , 1 (1):102-104.

[11] Mohd M, Haris BA, and Dinie NB. 2012. Tamarind seed extract enhances epidermal wound healing. International Journal of Biology; 4: 81-88.

[12] Nailufar, A., Basito, dan A Anam. 2012. Kajian karakteristik ketan hitam pada beberapa jenis pengemas selama penyimpanan. Jurnal Tekno Sains Pangan, 2(1), 122-132.

[13] Rachman, F., E.D. Logawa, H. Hegartika, P. Simanjuntak. 2008. Aktivitas antioksidan ekstrak tunggal dan kombinasinya dari tanaman Curcuma spp. Jurnal Ilmu Kefarmasian Indonesia. 6(2), 69-74.

[14] Ramli, R.A., dan A Jamil. 2012. Review acne analysis, grading and computational assessment methods: an overview. Skin Research and Technology, Singapore.

[15] Rosiyani. L., 2010. Evaluasi perubahan metabolit pada temulawak dengan waktu tanam yang berbeda.Institut Pertanian Bogor, Bogor.

[16] RuslayS., K.Shaari,Z.Zainal, Maulidiani, H.Sirat, and Israf. 2007. Characterization of the components present in the active fractions of health gingers (Curcuma xanthorrhiza and Zingiber zerumbet) . HPLC-DAD-ESIMS. 104(3), 1183-1191

[17] Septiana, A.T., Mustaufik, Dwiyanti, H., Muchtadi, D., Zakaria, F. dan Ola, M.M. (2006). Pengaruh spesies Zingiberaceae (jahe, temulawak, kunyit, dan kunyit putih) dan ketebalan irisan sebelum pengeringan terhadap kadar dan aktivitas antioksidan ekstrak aseton yang dihasilkan. Majalah Ilmu dan Teknologi Pertanian 26(2): 69-74.

[18] Setiawan. 2011. Berbagai Sumber dan Atlas Tumbuhan Obat Indonesia. Gramedia, Jakarta.

[19] Suratmo.2012. Reaksi Radikal Bebas dengan Suatu Materi, Kimia FMIPA Universitas Brawijaya, Malang.

[20] Surono, S. 2004. Probiotik Susu Fermentasi dan Kesehatan. Yayasan Pengusaha Makanan dan Minuman Seluruh Indonesia (YAPPMI).TRICK, Jakarta.

[21] Usmiati, S. dan A. Sudono. 2004. Pengaruh starter kombinasi bakteri dan khamir terhadap sifat fisikokimia dan sensori kefir. J. Pascapanen 1(1):12-21. 
[22] Utami, K., L Radiati, dan P Surjowardojo. 2011. Kajian Kualitas Susu SapiPerahPFH .(StudikasuspadaanggotaKoperasi Agro Niaga di Kacamatan Jabung Kabupaten Malang). Jurnal Ilmu-Ilmu Peternakan. 24(2),55-58.

[23] Virgita, V. M. 2015. Pemanfaatan Ketan Hitam Sebagai Masker Wajah. Universitas Negeri Semarang, Semarang.

[24] Wijayaningsih, dan Wiwik. 2008. Aktivitas anti bakteri in vitro dan sifat kimia kefir susu kacang hijau (Vigna Radiata) oleh pengaruh jumlah starter dan lama fermentasi. Universitas Dipenogoro, Semarang. 